\title{
ANALISIS FISIS MEMBRAN BIOFILTER ASAP ROKOK BERBAHAN BIJI KURMA UNTUK MENANGKAP RADIKAL BEBAS
}

\author{
Oleh: \\ Muthmainnah $^{1}$, Umaiyatus Syarifah ${ }^{2}$ dan Agus Mulyono ${ }^{3}$
}

\begin{abstract}
ABSTRAK: Rokok kretek merupakan salah satu produk budaya yang berurat akar pada kearifan lokal bangsa Indonesia. Merokok yang awalnya merupakan perlengkapan upacara adat telah bergeser menjadi kebiasaan umum dikalangan warga. Namun hingga saat ini isu pro-kontra rokok masih menjadi perbincangan hangat dikalangan masyarakat. Rokok yang terbuat dari tembakau jika dibakar akan menghasilkan beberapa reaksi kimia. Reaksi penguapan nikotin dan reaksi penguapan air. Nikotin yang menguap akan mengalami kondensasi kembali dalam paru-paru sehingga terjadi deposit nikotin yang menyebabkan penyakit kanker. Di sisi lain industri rokok yang berpijak pada kearifan lokal, mampu menjaga stabilitas perekonomian negara lewat sumbangsihnya dalam berbagai sektor salah satunya adalah Ekonomi. Komposit didefinisikan sebagai suatu sistem material yang tersusun dari campuran/kombinasi dua atau lebih unsur-unsur utama yang secara makro berbeda bentuk dan komposisi material namun tidak dapat dipisahkan. Biofilter komposit merupakan campuran dari beberapa bahan yang berasal dari alam dan diolah menjadi material komposit yang bertujuan untuk menyerap dan menghilangkan partikel radikal bebas yang terdapat di lingkungan. Kurma merupakan salah satu buah yang banyak dimanfaatkan dalam kedokteran ala nabi. Biji kurma mengandung senyawa-senyawa penting salah satunya fenolik bioaktif yang merupakan anti oksidan bagi makhluk hidup. Pada penelitian ini serbuk biji kuma digunakan sebagai membran komposit yang mampu menangkap beberapa jenis radikal bebas dari asap rokok. Pembuatan membran menggunakan biji kurma sebagai filler dengan variasi matriks PEG dan putuh telur. Variasi komposisi yang digunakan adalah 0.7 gram, 0.8 gram, 0.9 gram dan 1 gram filler dengan $0.3 \mathrm{ml}$ PEG dan putih telur. Hasil menunjukkan bahwa pada komposisi yang sama membran komposit biofilter berbahan biji kurma dengan matriks PEG memiliki kemampuan menangkap lima radikal bebas yaitu Hidroperoxida, $\mathrm{CO}^{2-}$, $\mathrm{C}$, Peroxy, $\mathrm{O}_{2}^{-}, \mathrm{CuOx}$, dan $\mathrm{CuGeO}_{3}$. Membran komposit biofilter berbahan biji kurma dengan matriks putih telur memiliki kemampuan menangkap empat radikal bebas yaitu $\mathrm{CO}_{2}{ }^{-}, \mathrm{C}, \mathrm{CuOx}, \mathrm{CuGeO}_{3}$.
\end{abstract}

Kata Kunci: Biofilter, Asap Rokok, Biji Kurma, Radikal Bebas, PEG, (Electron Spin Resonance) ESR, (Scanning Electron Microscope) SEM.

\begin{abstract}
Clove cigarettes was one of the cultural product that were rooted in the local wisdom indonesian nation. Formerly Smoking was the ceremonial paraphernalia traditionally had been shifted into a general habit among the community. But until now the issue of the pros and cons of cigarettes is still a warm conversation among the community. Cigarettes were made of tobacco when burned would produce some chemical reactions. Vaporized nicotine would evaporated1 again in the lungs so that in the accumulation of nicotine that causes cancer. On the other side of the tobacco industry was able to maintain the stability of the country's economy through its contribution in various sectors one of them was economy. composite material is defined as a system composed of a mixture of two or more of the major elements that are different shapes and different material composition but cannot be separated. Composite biofilter was a mixture of several substance derived from nature and processed into composite materials to absorb and eliminate free radical particles contained in environment. Date palm were one of the fruits are widely used by the prophet style treatment. Date palm Stones contain essential compounds bioactive phenolic that was become antioxidants for living organisms. In this study, date palm stones powder was used as a composite membrane capable of capturing multiple types of free radicals from cigarette smoke. Membranes producing use date palm stones as filler with matrix variations is PEG and egg white. The composition various used was $0.7 \mathrm{~g} ; 0.8 \mathrm{~g} ; 0,9 \mathrm{~g} ; 1 \mathrm{~g}$ of filler with $0.3 \mathrm{ml}$ of PEG and egg white as a matrix. The results showed that the biofilter composite membrane made of date palm stones of the same composition with PEG matrix has the ability to capture five free radicals, namely Hidroperoxida, $\mathrm{CO}^{2-}, \mathrm{C}, \mathrm{Peroxy}, \mathrm{O}_{2}^{-}, \mathrm{CuOx}$, dan $\mathrm{CuGeO}_{3}$. the
\end{abstract}

${ }_{1,2}$ dan 3 Staf Pengajar Jurusan Fisika Universitas Islam Negeri Maliki Malang 
biofilter composite membrane made of date palm stones with egg white as a matrix capable of capturing four free radicals that is $\mathrm{CO}_{2}^{-}, \mathrm{C}, \mathrm{CuOx}, \mathrm{CuGeO}_{3}$.

Keywords: biofilter, Smoke, Date Stones, Free Radicals, PEG, (Electron Spin Resonance) ESR, (Scanning Electron Microscope) SEM

\section{PENDAHULUAN}

Rokok kretek merupakan salah satu produk budaya yang berurat akar pada kearifan lokal bangsa Indonesia, merokok yang awalnya merupakan perlengkapan upacara adat telah bergeser menjadi kebiasaan umum dikalangan warga. Namun hingga saat ini isu prokontra rokok masih menjadi perbincangan hangat dikalangan masyarakat.

Rokok yang terbuat dari tembakau jika dibakar akan menghasilkan beberapa reaksi kimia. Reaksi pirolisa (pembakaran suhu $400^{\circ} \mathrm{C}-800^{\circ} \mathrm{C}$ ) dalam rokok membentuk senyawa kompleks yang mudah berdifusi dalam darah dan berbahaya bagi tubuh. Reaksi penguapan air dan nikotin dan terkondensasi, nikotin terkondensi juga mengalami kondensasi kembali dalam paru-paru sehingga terjadi deposit nikotin yang menyebabkan penyakit kanker. Sementara, Industri rokok yang berpijak pada kearifan lokal, mampu menjaga stabilitas perekonomian bangsa lewat sumbangsihnya dalam berbagai sektor salah satunya adalah Ekonomi. Cukai tembakau menjadi salah satu pemasok devisa Negara, selama tahun 19902008 telah menyumbang devisa sebanyak 87 Trilyun Rupiah, Industri ini juga memacu pertumbuhan daerah karena kebijakan implementasi $10 \%$ pajak rokok daerah.

Tidak semua produk rokok merugikan bagi tubuh, penelitian yang dilakukan oleh Prof. Sutiman BS dan Dr. Gretha Z menunjukkan bahwa tembakau pada rokok kretek mampu menjadi antitoksik bagi tubuh manusia dengan penambahan filter khusus (filter dengan tambahan Scavanger), Scavanger berfungsi sebagai agen pengubah asap rokok yang mengandung partikel berbahaya bagi kesehatan dan radikal bebas menjadi tidak berbahaya. Solusi pengendalian radikal bebas dan modifikasi elemen beracun dalam asap rokok menjadi tidak berbahaya bagi kesehatan, dengan riset menggunakan formula scavenger untuk mengendalikan dan memodifikasi asap rokok beracun menjadi tidak beracun. Dr. Arinto Yudi Ponco Wardoyo membuktikan bahwa rokok kretek yang filternya telah dibubuhi scavenger menghasilkan partikel asap yang lebih kecil 30nm dari pada partikel asap rokok kretek tanpa scavenger>80nm, rokok dengan penambahan scavenger radikal bebas tersaring dan tertangkap ketika asap melewati filter.[5]

Merujuk pada keterangan dalam al-Qur'an, Allah SWT telah mengisyaratkan bahwa segala sesuatu yang ada di alam semesta tidak diciptakan dengan kesia-siaan, bahkan debu kosmik juga memberikan manfaat bagi manusia. Al Qur'an telah dengan jelas mengisyaatkan kurma sebagai salah satu makanan dari surga yang diturunkan kebumi sebagai wujud karunia Allah kepada manusia.

Bii kopi memiliki kandungan antioksidan sebanyak 26\% mampu menangkap 7 jenis radikal bebas yang terkandung dalam asap rokok, sementara itu biji kurma memiliki kandungan antioksidan sebanyak 51- 66\% yang bergantung pada varietas kurma, diharapkan dengan pemanfaatan biji kurma sebagai biofilter akan menangkap lebih banyak radikal bebas yang terkandung dalam asap rokok. Sehingga penting untuk dilakukan 
penelitian tentang biji kurma sebagai bahan alternatif filter rokok untuk menangkal radikal bebas yang diemisikan oleh asap rokok.

Radikal bebas merupakan produk sampingan dari pembentukan energi selama proses metabolisme tubuh. Oksidasi lemak, karbohidrat, dan protein menghasilkan ATP (Adenosine triphospate) juga diperoleh anion superoksida dan hidroksil radikal yang biasa kita kenal sebagai radikal bebas. Selain dihasilkan oleh proses metabolisme dalam tubuh, radikal bebas juga dapat terbentuk melalui aktivitas pembakaran bahan bakar kendaraan bermotor, merokok, dan paparan sinar ultraviolet juga mampu merubah elektron setimbang dalam atom menjadi bersifat radikal.

Radikal bebas terbentuk secara in-vivo dan in-vitro melalui pemecahan satu molekul normal litik menjadi dua yang memerlukan energi tinggi, kehilangan satu electron dari molekul normal, dan penambahan electron pada molekul normal. Aktivasi Oksigen membuat oksigen bersifat radikal bebas yang biasa dikenal anion superoksida (O2•). Secara in-vitro, radikal ini membentuk senyawa kompleks dengan senyawa organik yang bergantung dengan sifat permukaan membrane, muatan listrik, sifat ikatan makromolekul, adanya enzim dan katalis. Selain terdapat dalam tubuh, radikal bebas juga banyak terdapat di lingkungan yang berasal dari logam,asap kendaraan bermotor, bahan beracun, asap rokok, radiasi matahari, polusi udara maupun bahan aditif.

Asap rokok dihasilkan dari pembakaran tidak sempurna tembakau dengan suhu tinggi sehingga dihasilkan emisi yang berupa gas dan partikel. Asap rokok meliputi asap utama (main stream) yang keluar dari pangkal batang rokok yang dihisap oleh perokok aktif dan asap sampingan (side stream) berasal dari pembakaran pada ujung rokok dan dikeluarkan ke lingkungan sekitar. Konsentrasi emisi asap yang dihasilkan oleh asap sampingan lebih besar dibandingkan dengan asap utama, karena tidak melaui proses penyaringan melalui filter rokok. Asap rokok mengandung lebih dari 4000 bahan kimia, partikel yang dihasilkan berukuran nanometer sampai mikrometer. Partikel ini terbentuk dari senyawa aromatik dan asap yang mempunyai gugus radikal bebas hingga mudah bereaksi dengan sel tubuh. Komponen yang terbentuk dari pembakaran asap rokok terdiri dari fase gas dan fase pertikel. Pada fase gas meliputi Amonia(NH3), karbon monoksida $(\mathrm{CO}), \mathrm{CO} 2, \mathrm{NO}, \mathrm{NO} 2$, hidrogen sianida $(\mathrm{HCN})$, volatile aldeheide (ethanol, formaldehyde, acroleine, crotonldehyde), benzene vapour, acetone, vinyl chloride, unsaturated hydrocarbons (butadiene, isoprene), dan fase partikel seperti Tar, nicotine, metals $(\mathrm{Cd}, \mathrm{Ni}$, $\mathrm{Fe}, \mathrm{Sn}$, chromium, arsenic), phenols, hydrogenic carsinogenic (benzopyrene, benzantharacene, chrysene) mampu bereaksi secara kimiawi dengan sel dan mengganggu system organ dalam tubuh manusia. Adanya konsentrasi senyawa radikal bebas dalam asap rokok menjadi penjelasan munculnya penyakit pada perokok aktif.

Antioksidan biasa digunakan untuk menunjukkan senyawa yang mencegah proses oksidasi karena fungsinya sebagai donor electron bagi radikal bebas. Vitamin E, $\alpha-$ tochopherol sangat penting bagi kesehatan beberapa hewan, atau yang biasa dikenal sebagai antioksidan. Hidroksil radikal segera bereaksi dengan anion radikal superperoksida. Secara alami tubuh manusia memiliki kemampuan proteksi terhadap radikal bebas melalui produksi enzim superperoksida dismutase (SOD), glutation peroksidase (GSH Px), katalase, dan protein glutatio yang merupakan antioksidan endogen, cara kerja antioksidan ini dengan didukung oleh antioksidan eksogen dari luar 
tubuh seperti Fenol, Betakaroten, Vitamin E, Vitamin C, Flavonoid yang banyak dihasilkan oleh tumbuhan. [2]

Biji kurma memiliki keunggulan asam amino pada Asam Aspartat, Aspartamin, Asam Glutamat, Leusin dan Isoleusin. Biji kurma memiliki kandungan asam lemak rantai ganda (unsaturated fattyacid). Disebutkan bahwa terdapat Asam Oleat sebanyak 48.5 $\mathrm{g} / 100 \mathrm{~g}$ biji kurma, diikuti dengan Asam Linoleat sebanyak $3.3 \mathrm{~g} / 100 \mathrm{~g}$ biji kurma. Kandungan asam lemak jenuh rantai sedang seperti Laurat, Palmitat, dan Stearat juga cukup mendominasi kandungan nutritif dari biji kurma, dengan total sekitar 40-45\% berat kering.

Tabel 1. Komposisi daging buah dan biji kurma

\begin{tabular}{ccccc}
\hline Komponen & Daging buah & Biji Segar & Biji Kering & Biji Sangrai \\
\hline Moisture & $9.7-17.7$ & $8.6-12.5$ & - & - \\
Protein & $1.1-3.0$ & $4.8-6.9$ & $5.2-5.6$ & 7.1 \\
Lemak & $0.5-3.3$ & $5.7-8.8$ & $10.2-12.7$ & 8.1 \\
Abu & $1.4-2.6$ & $0.8-1.1$ & $1.1-1.2$ & 1.0 \\
Serat terlarut & $5.9-18.4$ & $67.6-74.2$ & - & - \\
Karbohidrat & $72.8-85.0$ & $2.4-4.7$ & $81.0-83.1$ & 62.3 \\
\hline
\end{tabular}

Menurut Najafi [4] biji kurma memiliki kandungan antioksidan cukup tinggi diantara beberapa jenis biji lain seperti biji anggur. Biji kurma mengandung 3.10-7.10\% moisture, 2.30-6.40\% protein, 5.00-13.20 lemak, $0.90-1.80 \%$ abu dan $22.50-80.20 \%$ serat terlarut, biji kurma juga memiliki kandungan fenol yang tinggi (3102-4430 mg ) dan $1100 \mathrm{mg}$ asam Gallic. Biji kurma mengandung senyawa-senyawa penting seperti fenolik bioaktif dan serat pangan, pemberian ekstrak biji kurma pada tikus juga menunjukkan pengembalian fungsi penawar racun dan berakibat perlindungan terhadap Carbontetrachloride Hepatotoxicity pada hati tikus.

Komposit merupakan material campuran yang sedikitnya terdiri atas dua fasa yang berbeda tanpa mengalami reaksi kimia, yang bertujuan untuk mendapatkan material baru yang kuat, tangguh dan ulet sesuai sifat dasar dari bahn yang dignakan. Fasa dalam campuran komposit meliputi fasa pendispersi dan fasa terdispersi, pendispersi atau matriks merupakan bahan yang berfungsi sebagai pengikat yang memiliki Modulus Young lebih kecil dari bahan terdispersi. Filler atau bahan pengisi adalah material yang terdispersi oleh matriks sehingga selalu berada di dalam matriks. Berdasarkan bentuknya, filler dapat digolongkan menjadi komposit partikel, komposit serat, dan komposit structural. Komposit partikel interaksi yang terjadi antara matriks dan filler dalam skala makroskopis dimana partikel pengisi terdistribusi secara merata dalam matriks.

Biofiltrasi merupakan teknik pengendalian polusi dalam hal ini bisa berupa radikal bebas menggunakan material hayati untuk menangkap dan menghilangkan proses pembentukan polutan secara biologis [1]. Biofilter Komposit merupakan campuran dari beberapa bahan yang berasal dari alam dan diolah menjadi material komposit yang 
bertujuan untuk menyerap dan menghilangkan partikel radikal bebas yang terdapat di lingkungan.

Filter rokok secara khusus didesain untuk menyerap asap dan akumulasi partikulat asap rokok. Filter juga mencegah masuknya tembakau ke dalam mulut perokok dan melindungi bagian mulut yang terpapar tembakau dan asap selama merokok. Secara umum filter terdiri dari beberapa komponen, diantaranya adalah sumbat . Filter rokok mampu menyaring unsur logam yang terkandung dalam asap rokok dengan prosentase $0.7-54 \%$ sedangkan pada rokok kretek jumlah unsur logam yang terbawa oleh puntung $\quad 0.2-36 \%$. [3]

Spektroskopi Elektro Spin Resonance (ESR) merupakan teknik untuk mengetahui senyawa yang memiliki elektron tak berpasangan seperti radikal bebas organic maupun senyawa radikal bebas anorganik maupun senyawa kompleks anorganik yang memiliki ion logam transisi.Radikal bebas biasanya memproduksi electron tak berpasangan turunan eektron yang dihasilkan oleh kerusakan radiasi dari radiasi pengion.Senyawa organik stabil biasanya mempunyai kulit electron tertutup atau tidak mempunyai electron tak berpasangan sehingga tidak ada spin electron yang terukur. Spektroskopi spin electron dalam senyawa organic terbatas untuk mengetahui reaksi intermediet (radikal bebas dalam keadaan triplet), dalam bidang biologi, ESR biasanya dipakai untuk mengetahui keberadaan inti logam dalam grup prostetik dan pada tingkat rendahuntuk mengetahui enzim radikal.

Proses pengambilan data dilakukan dengan membakar rokok kretek dan diberikan membran yang telah dibuat kemudian dihubungkan dengan pipet dan penghisap. Penghisapan dilakukan secara berkala hingga asap mengalir. Setelah itu sampel dalam tabung/pipet yang terletak di tengah-tengah kumparan dimana kumparan yang dipilih adalah kumparan yang sesuai jangkauan frekuensinya dengan sampel, seperti ESR yang memiliki jangkauan $\mathrm{f}$ yang berbeda-beda.

Pengamatan dilakukan pada kurva hasil bentukan oleh osciloskop. Apakah muncul hasil resonansi berbentuk cekungan, diamati dan direkam data kurvanya pada osciloskop dan dicatat $\mathrm{f}$ dan I sambil terus melakukan penghisapan agar asap tetap berada pada pipet pengukuran. Dimana pengubahan dilakukan untuk nilai $f$ saja.

Pada saat proses pengukuran, pipet pengukuran ESR diganti dengan pipet tetes sebagai wadah pengukuran. Pipet tetes digunakan sebagai wadah pengukuran dikarenakan sulitnya mendapatkan ESR.

Analisis data dilakukan melalui perhitungan dari perolehan pengukuran rokok kretek yang ditambah dengan membran bahan komposit serbuk tanaman delima. Proses perhitungan ini menggunakan persamaan:

$$
\mathrm{B}=\mu_{0}(4 / 5)^{3 / 2} \frac{n}{r} \mathrm{I}
$$

Keterangan :

$$
\begin{array}{cl}
\mu_{0}=1,2566 \times 10^{-6} \mathrm{Vs} / \mathrm{Am} & \mathrm{n}=\text { Jumlah lilitan kumparan } \\
\mathrm{r}=\text { Jari-jari kumparan } & \mathrm{I}=\text { Besar arus pada kumparan } \\
\mathrm{hf}=\mathrm{g} \mu_{\mathrm{B}} \mathrm{B} \rightarrow \mathrm{g}=\frac{\mathrm{hf}}{\operatorname{GB~B}} &
\end{array}
$$




$$
\delta \mathrm{g}=\frac{\sqrt{\sum_{n-\mathbf{1}}^{k}|\boldsymbol{g}-\overline{\boldsymbol{g}}| \mathbf{2}}}{\boldsymbol{k}(\boldsymbol{k}-\mathbf{1})}
$$

Keterangan :

$$
\begin{aligned}
& \delta \mathrm{g}=\text { Deviasi } \mathrm{g} \\
& \mathrm{g}=\text { Faktor Lande } \\
& \mathrm{B}=\text { Medan magnet }
\end{aligned}
$$

$$
\begin{aligned}
& \mathrm{f}=\text { Frekuensi } \\
& \mu_{\mathrm{B}}=\text { Bilangan Magnetik Bohr } \\
& \mathrm{h}=\text { Konstanta Planck }
\end{aligned}
$$

Hasil perhitungan nilai faktor $\mathrm{g}$ yang didapatkan kemudian dibandingkan dengan tabel nilai faktor $\mathrm{g}$ pada literatur untuk menentukan jenis radikal bebas pada asap rokok. Kemudian hasil penyerapan asap rokok pada membran komposit difoto dengan set peralatan Scanning Electron Microscope (SEM). Data yang diperoleh dari Scanning Electron Microscope (SEM) berupa foto kerapatan dan porositas komposit dari masingmasing variasi. Pengujian kerapatan dan porositas pada biofilter juga dilakukan menggunakan perumusan :

$$
\begin{aligned}
& \operatorname{Kerapatan}(\rho)=\frac{\boldsymbol{m}(\boldsymbol{g})}{\boldsymbol{v}\left(\boldsymbol{c m}^{3}\right)} \\
& \text { Porositas }(\%)=\frac{\mathrm{mb}-\mathrm{mk}}{V b} \times \frac{1}{\tilde{\mathrm{n}} \text { (air) }} \times 100 \%
\end{aligned}
$$

Keterangan :

$\rho=$ kerapatan $\left(\mathrm{g} / \mathrm{cm}^{3}\right)$

$\mathrm{v}=$ volume membran $\left(\mathrm{cm}^{3}\right)$

$$
\begin{aligned}
& \mathrm{m}=\text { massa membran }(\mathrm{g}) \\
& \mathrm{m}_{\mathrm{b}}=\text { massa basah }(\mathrm{g}) \\
& \rho(\text { air })=\text { densitas air } 1\left(\mathrm{~g} / \mathrm{cm}^{3}\right)
\end{aligned}
$$$$
\mathrm{m}_{\mathrm{k}}=\text { massa kering }(\mathrm{g})
$$

\section{HASIL DAN PEMBAHASAN}

Pembuatan membran komposit berbahan biji kurma dengan variasi suhu terdiri dari beberapa tahapan. Tahapan pertama adalah Bahan Biji kurma dihaluskan dan diayak menggunakan ayakan mesh 100 Mesh dan 250 Mesh. Tahap kedua menimbang bahan menggunakan neraca analitik dengan masing-masing variasi 0,7 gram, 0,8 gram, 0,9 gram dan 1 gram. Masing-masing bahan kemudian dimasukkan pada crusible dan dicampur dengan polietilon glikol (PEG) dan putih telur sebanyak 0,3 ml. Bahan selanjutnya diaduk sampai homogen agar dapat menjadi membran yang dapat menangkap radikal bebas pada asap rokok. Tahapan ketiga adalah mencetak bahan menggunakan selang berdiameter 7 mm dan dibiarkan sampai kering. Setelah membran komposit kering maka dikeluarkan dari cetakan dan dioven dengan suhu 105 oC selama 20 menit umtuk menghilangkan kadar air pada membran komposit.

Pengujian radikal bebas pada asap rokok filter menggunakan ESR (Electron Spin Resonance) Leybold Heracus, terlebih dahulu dilakukan kalibrasi alat dengan menggunakan DPPH. DPPH yang diletakkan didalam kumparan kemudian ditentukan nilai frekuensi (f) dan nilai arus (I) yang kemudian dilakukan perhitungan faktor g. Hasil nilai DPPH pada penelitian ini didapatkan nilai frekuensi sebesar $34,3 \mathrm{~Hz}$ dan nilai arus sebesar 0,268 A. Dari hasil nilai frekuensi dan arus dapat ditentukan nilai medan magnet (B) sebesar 0,00113399 dan nilai faktor g dari DPPH sebesar 2,1609855. Setelah niali DPPH sudah ditentukan kemudian DPPH dilepas dari kumparan dan dilanjutkan dengan 
menentukan jenis dugaan radikal bebas asap rokok filter kretek cigarettes. Perhitungan faktor g dari ESR (electron spin resonance) leybold Heracus digunakan sebagai indikator ada tidaknya penyerapan radikal bebas terhadap membran komposit biofilter daun tembakau-biji kurma, yang kemudian dibandingkan nilai faktor g pada tabel radikal bebas. hasil dari dugaan radikal bebas asap rokok filter kretek cigarettes ditampilkan pada tabel 2 .

Komposit biofilter yang sudah dibuat dan diuji untuk membuktikan bahwa sampel tersebut dapat menangkap radikal bebas dengan baik, seperti yang ditunjukkan pada pada tabel 4.2 dan 4.3. Sebelumnya ESR mendeteksi 7 jenis radikal bebas pada rokok kretek non filter, yaitu Hidroperoxida, CO2-, C, Peroxy, O-2, CuOx, dan CuGeO3. Data tabel 3. menunjukkan kemampuan membran komposit biofilter (PEG) dengan serbuk biji kurma mampu menangkap 5 jenis radikal bebas, yaitu Hidroperoxida, $\mathrm{CO} 2-$, $\mathrm{C}$, peroxy dan O2-. Sedangkan pada biofilter biji kurma bermatriks putih telur hanya mampu menangkap 4 radikal bebas, yaitu $\mathrm{CO} 2-, \mathrm{C}, \mathrm{CuOx}, \mathrm{CuGeO}$. Dari hasil uji ESR terlihat bahwa komposit biofilter dengan menggunakan komposit PEG cenderung lebih efektif menangkap radikal bebas dari pada putih telur.

Hal ini disebabkan kecilnya nilai porositas dan besarnya kerapatan membran yang dibuat. Besar rata-rata pori-pori yang ditunjukkan oleh hasil SEM (Gambar 1) memperlihatkan bahwa pori-pori permukaan membran tergolong besar bila dibandingkan dengan jari-jari radikal bebas. Ini menunjukkan peran pori-pori pada permukaan membran sangat sedikit pengaruhnya terhadap penangkapan radikal bebas asap rokok. Permukaan membran tersusun dari material bahan penyusun membran yang kurang padat dan merata. Pengaruh terbesar terletak pada proses pembuatan membran biofilter dengan pemberian besar tekanan yang berbeda disetiap sisi permukaan. Pori-pori, porositas dan kerapatan membran biofilter terbentuk karena adanya komponen penyusun yang terdapat pada PEG dan putih telur. Dengan PEG dapat meningkatkan keteraturan bentuk pori-pori pada membran sehingga struktur pori lebih rapat. Sedangkan putih telur memiliki struktur yang dibentuk oleh serabut-serabut protein yang terjalin membentuk jala.

Tabel 2. Jenis Dugaan Radikal Bebas Asap Rokok Filter Kretek Cigarettes

\begin{tabular}{cc}
\hline No. & Jenis Radikal Bebas Asap Rokok Kretek \\
\hline 1. & Hidroperoksida \\
2. & $\mathrm{CO}_{2}^{-}$ \\
3. & $\mathrm{C}$ \\
4. & Peroxy \\
5. & $\mathrm{O}_{2}^{-}$ \\
6. & $\mathrm{CuOx}^{-}$ \\
7. & $\mathrm{CuGeO}_{3}$ \\
\hline
\end{tabular}


Tabel 3. Hasil Pengujian Radikal Bebas pada Biofilter Berbahan Biji Kurma dengan matriks PEG

\begin{tabular}{|c|c|c|}
\hline Suhu & $\operatorname{Massa}(g)$ & Radikal Bebas \\
\hline \multirow[t]{4}{*}{ Fresh } & 0.7 & $\mathrm{CuOx}, \mathrm{CuGeO}_{3}$ \\
\hline & 0.8 & $\mathrm{CuOx}, \mathrm{CuGeO}_{3}$ \\
\hline & 0.9 & $\mathrm{CuOx}, \mathrm{CuGeO}_{3}$ \\
\hline & 1 & $\mathrm{CuOx}, \mathrm{CuGeO}_{3}$ \\
\hline \multirow[t]{4}{*}{ Sangrai } & 0.7 & $\mathrm{CuOx}, \mathrm{CuGeO}_{3}$ \\
\hline & 0.8 & $\mathrm{CuOx}, \mathrm{CuGeO}_{3}$ \\
\hline & 0.9 & $\mathrm{CuOx}, \mathrm{CuGeO}_{3}$ \\
\hline & 1 & $\mathrm{CuOx}, \mathrm{CuGeO}_{3}$ \\
\hline \multirow[t]{4}{*}{$50^{\circ} \mathrm{C}$} & 0.7 & $\mathrm{CuOx}, \mathrm{CuGeO}_{3}$ \\
\hline & 0.8 & $\mathrm{CuOx}, \mathrm{CuGeO}_{3}$ \\
\hline & 0.9 & $\mathrm{CuOx}, \mathrm{CuGeO}_{3}$ \\
\hline & 1 & $\mathrm{CuOx}, \mathrm{CuGeO}_{3}$ \\
\hline \multirow[t]{4}{*}{$100^{\circ} \mathrm{C}$} & 0.7 & $\mathrm{CuOx}, \mathrm{CuGeO}_{3}$ \\
\hline & 0.8 & $\mathrm{CuOx}, \mathrm{CuGeO}_{3}$ \\
\hline & 0.9 & $\mathrm{CuOx}, \mathrm{CuGeO}_{3}$ \\
\hline & 1 & $\mathrm{CuOx}, \mathrm{CuGeO}_{3}$ \\
\hline
\end{tabular}

Tabel 4. Hasil pengujian Radikal bebas pada biofilter berbahan biji kurma dengan putih telur sebagai matriks

\begin{tabular}{|c|c|c|}
\hline Suhu & $\operatorname{Massa}(g)$ & Radikal Bebas \\
\hline \multirow[t]{4}{*}{ Fresh } & 0.7 & Hydroperoxide, $\mathrm{SO}_{4}^{-}$, Peroxy, $\mathrm{O}_{2}^{-}$ \\
\hline & 0.8 & Hydroperoxide, $\mathrm{SO}_{4}^{-}$, Peroxy, $\mathrm{O}_{2}^{-}$ \\
\hline & 0.9 & Hydroperoxide, $\mathrm{SO}_{4}{ }^{-}$, Peroxy, $\mathrm{O}_{2}^{-}$ \\
\hline & 1 & Hydroperoxide, $\mathrm{SO}_{4}{ }^{-}$, Peroxy, $\mathrm{O}_{2}^{-}$ \\
\hline \multirow[t]{4}{*}{ Sangrai } & 0.7 & Hydroperoxide, $\mathrm{SO}_{4}{ }^{-}$, Peroxy, $\mathrm{O}_{2}^{-}$ \\
\hline & 0.8 & Hydroperoxide, $\mathrm{SO}_{4}{ }^{-}$, Peroxy, $\mathrm{O}_{2}^{-}$ \\
\hline & 0.9 & Hydroperoxide, $\mathrm{SO}_{4}{ }^{-}$, Peroxy, $\mathrm{O}_{2}^{-}$ \\
\hline & 1 & Hydroperoxide, $\mathrm{SO}_{4}^{-}$, Peroxy, $\mathrm{O}_{2}^{-}$ \\
\hline \multirow[t]{4}{*}{$50^{\circ} \mathrm{C}$} & 0.7 & Hydroperoxide, $\mathrm{SO}_{4}{ }^{-}$, Peroxy, $\mathrm{O}_{2}^{-}$ \\
\hline & 0.8 & Hydroperoxide, $\mathrm{SO}_{4}{ }^{-}$, Peroxy, $\mathrm{O}_{2}^{-}$ \\
\hline & 0.9 & Hydroperoxide, $\mathrm{SO}_{4}^{-}$, Peroxy, $\mathrm{O}_{2}^{-}$ \\
\hline & 1 & Hydroperoxide, $\mathrm{SO}_{4}^{-}$, Peroxy, $\mathrm{O}_{2}^{-}$ \\
\hline \multirow[t]{4}{*}{$100^{\circ} \mathrm{C}$} & 0.7 & Hydroperoxide, $\mathrm{SO}_{4}^{-}$, Peroxy, $\mathrm{O}_{2}^{-}$ \\
\hline & 0.8 & Hydroperoxide, $\mathrm{SO}_{4}^{-}$, Peroxy, $\mathrm{O}_{2}^{-}$ \\
\hline & 0.9 & Hydroperoxide, $\mathrm{SO}_{4}^{-}$, Peroxy, $\mathrm{O}_{2}^{-}$ \\
\hline & 1 & Hydroperoxide, $\mathrm{SO}_{4}^{-}$, Peroxy, $\mathrm{O}_{2}^{-}$ \\
\hline
\end{tabular}




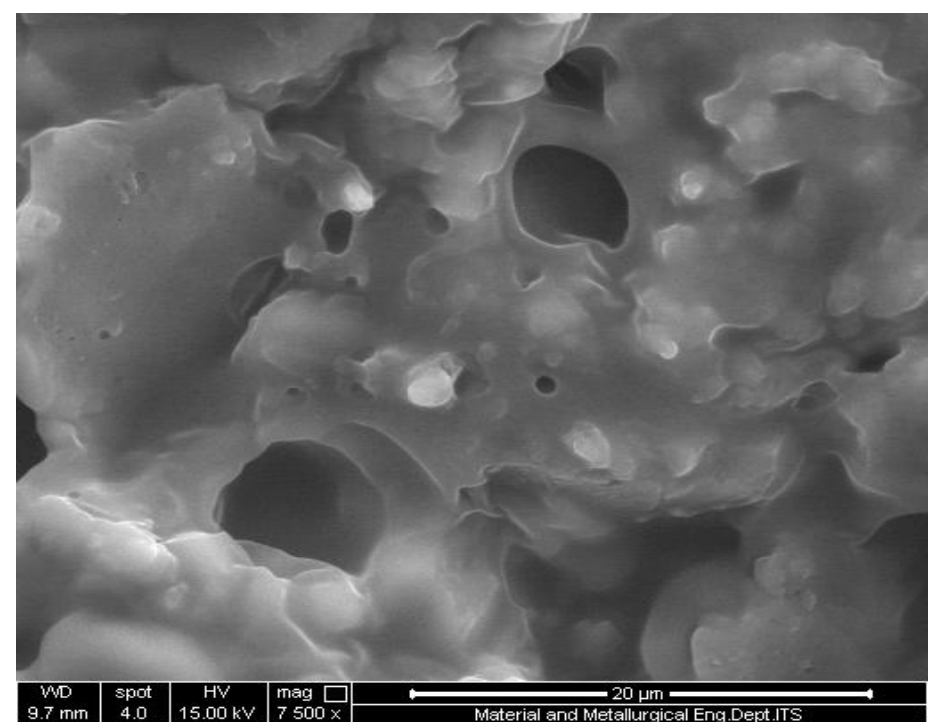

Gambar 1. Hasil SEM 0.7g Biji Kurma dengan matriks PEG pada perbesaran 7500 kali

\section{KESIMPULAN}

Membran komposit biofilter berbahan biji kurma dengan matriks PEG memiliki kemampuan menangkap lima radikal bebas yaitu Hidroperoxida, $\mathrm{CO}^{2-}, \mathrm{C}$, peroxy dan $\mathrm{O}_{2}^{-}$.. Membran komposit biofilter berbahan biji kurma dengan matriks putih telur memiliki kemampuan menangkap empat radikal bebas yaitu $\mathrm{CO}_{2}^{-}, \mathrm{C}, \mathrm{CuOx}, \mathrm{CuGeO}_{3}$. Sehingga dapat disimpulkan komposisi biofilter mempengaruhi kemampuan penangkapan radikal bebas asap.

\section{DAFTAR PUSTAKA}

[1] Idrus, Ahmad Zaiyad. B. Biofilter Aplication for Leachate Treatment. 2010. Universiti Teknologi Malaysia. Undergraduate Theses.

[2] Minarno, Eko Budi dan Liliek Hariani. 2008. Gizi dan Kesehatan Perspektif Al-Qur'an dan Sains. Malang : UIN Malang Press.

[3] Mulyaningsih, Rina. Penentuan Unsur Logam dan Distribusinya dalam Komponen Rokok dengan Metode KO-Analisis Aktivasi Neutron instrumental. Jurnal Teknologi Rekator Nuklir Vol. 11 No. 1 Pebruari 2009: 25-35.

[4] Najafi, Mohammad B. Habibi. Date Seeds: A Novel and Inexpensive Source of Dietary Fiber. 2011 International Conference on Food Engineering and Biotechnology IPCBEE vol.9 (2011) (C) (2011) IACSIT Press, Singapoore.

[6] Zahar, Gretha., Sumitro, Sutiman Bambang. 2011. Divine Kretek Rokok Sehat. Masyarakat Bangga Produk Indonesia (MBPI) 